UNITED STATES DEPARTMENT OF THE INTERIOR

GEOLOGICAL SURVEY

\title{
Analytical results and sample locality map \\ of stream-sediment and heavy-mineral-concentrate samples \\ from the Little Lake Canyon (CDCA 157) and Owens Peak (CDCA 158) \\ Wilderness Study Areas, Inyo and Kern Counties, California
}

\section{By}

David E. Detra, Marjorie S. Erickson, Robert E. Tucker, Michael F. Diggles, and Nancy L. Parduhn

Open-File Report 85-34

This report is preliminary and has not been reviewed for conformity with U.S. Geological Survey editorial standards and stratigraphic nomenclature. Any use of trade names is for descriptive purposes only and does not imply endorsement by the USGS. 


\section{CONTENTS}

Studies related to wilderness $\ldots \ldots \ldots \ldots \ldots \ldots \ldots \ldots \ldots \ldots \ldots \ldots \ldots \ldots \ldots \ldots \ldots \ldots \ldots$

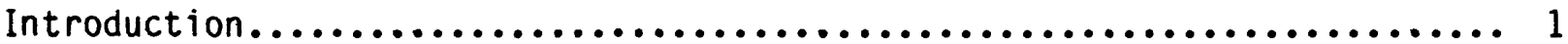

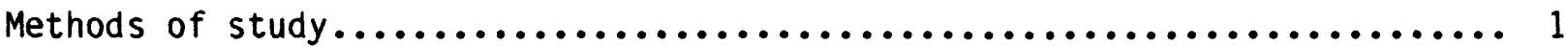

Sample media........................................ 1

Sample collection........................................ 3

Stream-sediment samples.............................. 3

Heavy-mineral-concentrate samples...................... 3

Sample preparation...................................... 3

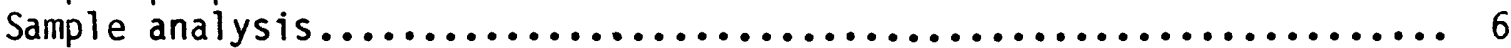

Spectrographic method.............................. 6

Rock Analysis Storage System (RASS) .......................... 6

Description of Data Tables.................................. 6

References cited........................................ 7

\section{ILLUSTRATIONS}

FIGURE 1.--Location map of the Little Lake Canyon and Owens Peak Wilderness Study Areas, Inyo and Kern Counties, California......... 2

FIGURE 2.--Site location map for the Little Lake Canyon and Owens Peak

Wilderness Study Areas, Inyo and Kern Counties, California......... 4

FIGURE 3.--Graphical representation of the sampling design........... 5

\section{TABLES}

TABLE 1.--List of duplicate samples collected in the Little Lake Canyon and Owens Peak Wilderness Study Areas, Inyo and Kern

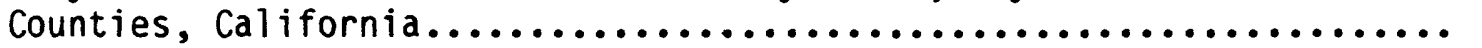

TABLE 2. Limits of determination for spectrographic analysis of

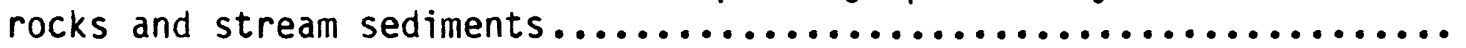

TABLE 3. Analytical results for the minus-80-mesh stream-sediment samples from the Little Lake Canyon Wilderness Study Area, Inyo County, California.

TABLE 4. Analytical results for the nonmagnetic heavy-mineral-concentrate samples from the Little Lake Canyon Wilderness Study Area Inyo County, California..................................

TABLE 5. Analytical results for the minus-80-mesh stream-sediment samples from the Owens Peak Wilderness Study Area, Inyo and

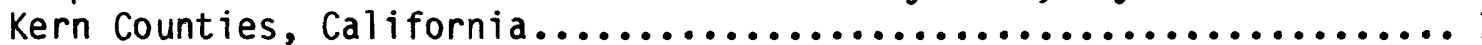

TABLE 6. Analytical results for the nonmagnetic heavy-mineralconcentrate samples from the Owens Peak Wilderness Study Area, Inyo and Kern Counties, California. 


\title{
STUDIES RELATED TO WILDERNESS
}

\author{
Bureau of Land Management Wilderness Study Areas
}

The Federal Land Policy and Management Act (Public Law 94-579, October 21, 1976) requires the U.S. Geological Survey and the U.S. Bureau of Mines to conduct mineral surveys on certain areas to determine their mineral values, if any. Results must be made available to the public and be submitted to the President and the Congress. This report presents the results of a mineral survey of the Little Lake Canyon and Owens Peak Wilderness Study Area, California Desert Conservation Area, Inyo and Kern Counties, California.

\section{INTRODUCTION}

In the spring of 1982 the U.S. Geological Survey conducted a reconnaissance geochemical survey of the Little Lake Canyon and Owens Peak Wilderness Study Areas, Inyo and Kern Counties, California.

The Little Lake Canyon and Owens Peak Wilderness Study Areas comprise about $95 \mathrm{mi}^{2}\left(247 \mathrm{~km}^{2}, 61,200\right.$ acres) in southeastern Cal ifornia. The study areas are located approximately $20 \mathrm{mi}(32 \mathrm{~km})$ northwest of Ridgecrest (fig. 1). Access to the study areas is provided by route 6 to the east, Walker pass (route 178) to the south, and unimproved dirt roads in other directions. The Little Lake Canyon and Owens Peak Wilderness Study Areas are located in the Basin and Range Province. The elevation ranges from 8,400 $\mathrm{ft}$ $(2560 \mathrm{~m})$ at the summit of Owens Peak down to approximately 3,500 ft (1067 m) in the valley floor. The main portion of the study areas are mountainous which grade into pediments near the basin floor. The climate is arid to semiarid; Cresote bush and associated flora are the dominant vegetation in the study areas.

The predominant rocks in the study areas are granites of Jurassic or Cretaceous age which form the southern part of the eastern flank of the Sierra Nevada Range. These rocks are mainly granodiorite and quartz monzonites and comprise part of the Sierra Nevada Batholith. The oldest exposed rocks in the study areas are a narrow northwest-southeast trend of Pre-Cretaceous metasediments just south of Indian Wells Canyon. There are also Pleistocene non-marine sediments found in the lower reaches of the more prominent canyons.

\section{METHODS OF STUDY}

\section{Sample Media}

Analyses of the stream-sediment samples represent the chemistry of the rock material eroded from the drainage basin upstream from each sample site. Such information is useful in identifying those basins which contain concentrations of elements that may be related to mineral deposits. Heavy-mineral-concentrate samples provide information about the chemistry of certain minerals in rocks eroded from the drainage basin upstream from each sample site. The selective concentration of minerals, many of which may be ore-related, permits determination of some elements that are not easily detected in stream-sediment samples. 


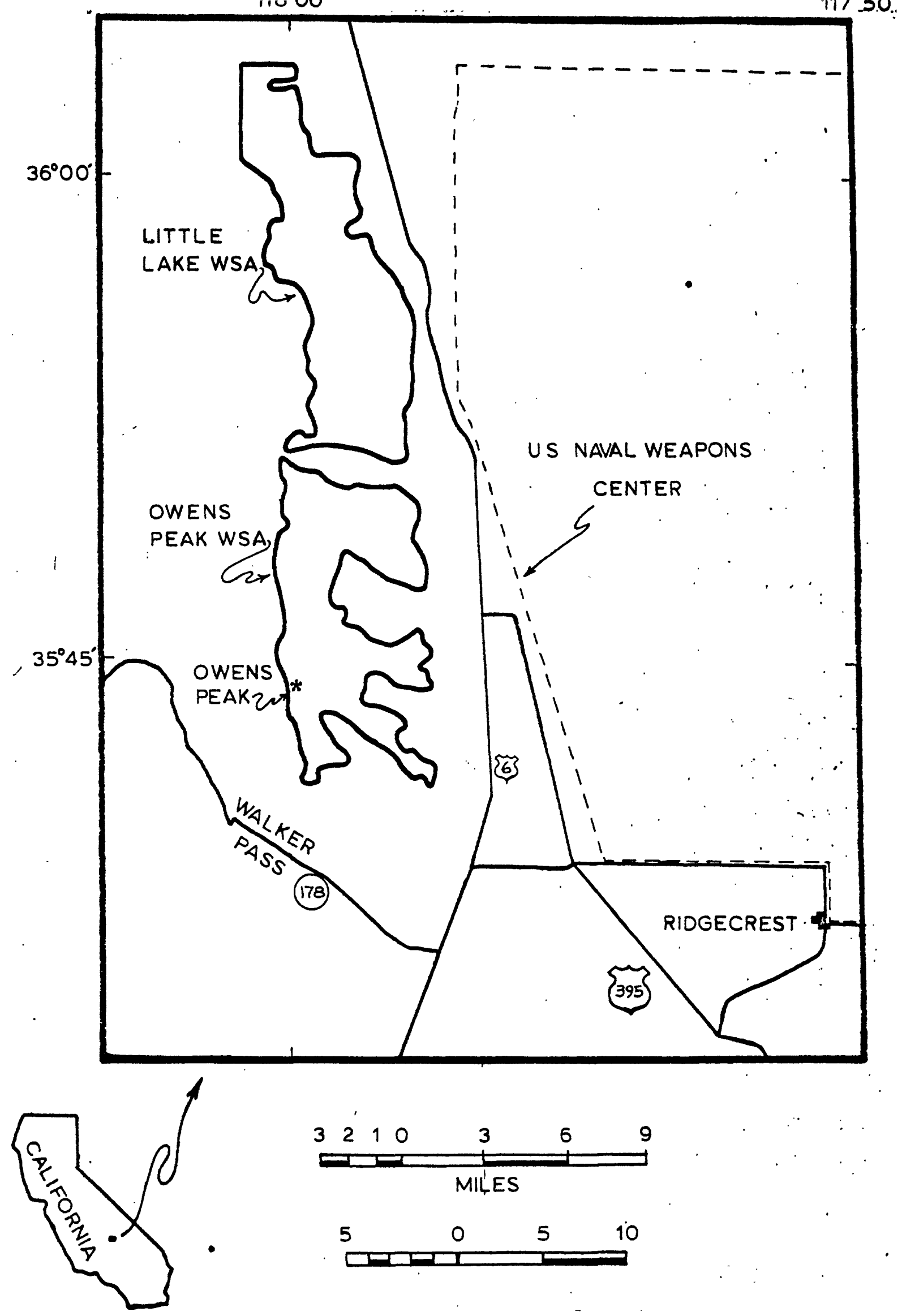

Figure 1. Location map of the Little Lake Canyon and Owens Peak Wilderness Study Areas, Inyo and Kern Counties, California (WSA - Wilderness Study Area). 


\section{Sample Collection}

Samples were collected at 100 sites (fig. 2). At nearly all of those sites, both a stream-sediment sample and a heavy-mineral-concentrate sample were collected. Sampling density was about 1 sample site per square mile for the stream sediments and heavy-mineral concentrates. The area of the drainage basins sampled ranged from $.2 \mathrm{mi}^{2}$ to $.4 \mathrm{mi}^{2}$.

The sampling was conducted on a low-level, unbalanced, hierarchial design utilizing 1-sq-mi cells (fig. 3). The sediment from a randomly selected first-order drainage basin, with an areal extent of approximately 0.2 to 0.4 $\mathrm{sq} \mathrm{mi}(0.5$ to $1 \mathrm{sq} \mathrm{km})$ was collected for each cell. The cells represent level 1 of the sampling design, and variance among cells represents the regional variance. Level 2 of the sampling design represents variance between basins within cells. A duplicate basin sample was collected from each of five randomly selected cells in a basin adjacent to the original cell basin. Level 3 of the sampling design represents variance within a basin and is based on sampling of duplicate sites ( $30 \mathrm{~m}$ apart) within the duplicate basins. Level 4 of the sampling design represents duplicate analyses of the duplicate samples. Table 1 lists the duplicate samples collected during the survey.

\section{Stream-sediment samples}

The stream-sediment samples consisted of active alluvium collected primarily from first-order (unbranched) and second-order (below the junction of two first-order) streams as shown on figure 2. Each sample was composited from at least five areas within a length of about $50 \mathrm{ft}(17 \mathrm{~m})$ and screened to minus $2 \mathrm{~mm}$ (10 mesh). Ten to 15 pounds $(4.5-7.0 \mathrm{~kg})$ of screened material were collected at each site and hand mixed.

\section{Heavy-mineral-concentrate samples}

Heavy-mineral-concentrate samples were collected from the same active alluvium as the stream-sediment samples. Each bulk sample was screened with a $2.0-\mathrm{mm}$ (10-mesh) screen to remove the coarse material. The less than $2.0-\mathrm{mm}$ fraction was panned until most of the quartz, feldspar, organic material, and clay-sized material were removed.

\section{Sample Preparation}

The stream sediment samples were air dried, then sieved using 80 mesh $(0.17 \mathrm{~mm})$ stainless steel sieves. The portion of the sediment passing through the sieve was saved for analysis.

After air drying, bromoform (specific gravity 2.8) was used to remove the remaining quartz and feldspar from the heavy-mineral-concentrate samples that had been panned in the field. The resultant heavy mineral sample was separated into three fractions using a large electromagnet (in this case a modified Frantz Isodynamic Separator). The most magnetic material, primarily magnetite, was not analyzed. The second fraction, largely ferromagnesian silicates and iron oxides, was saved for archival storage. The third fraction (the least magnetic material which may include the nonmagnetic ore minerals, zircon, sphene, etc.) was split using a Jones splitter. One split was handground for spectrographic analysis; the other split was saved for 

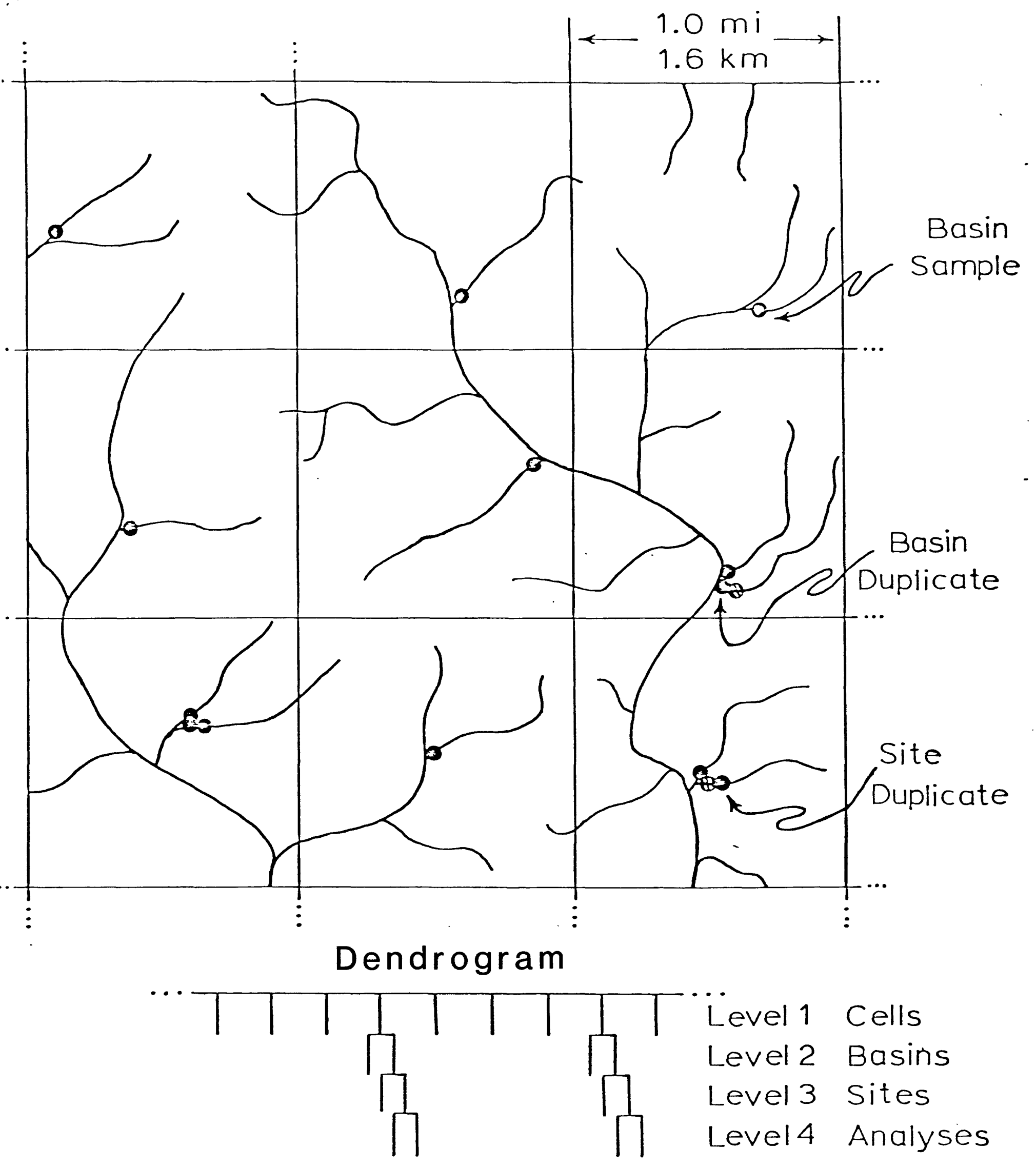

Figure 3.--Graphical representation of the sampling design. 
mineralogical analysis. These magnetic separates are the same separates that would be produced by using a Frantz Isodynamic Separator set at a slope of $15^{\circ}$ and a tilt of $10^{\circ}$ with a current of 0.1 ampere to remove the magnetite and ilmenite, and a current of 1.0 ampere to split the remainder of the sample into paramagnetic and nonmagnetic fractions.

\section{Sample Analysis}

\section{Spectrographic method}

The stream-sediment, heavy-mineral-concentrate, and rock samples were analyzed for 31 elements using a semiquantitative, direct-current arc emission spectrographic method (Grimes and Marranzino, 1968). The elements analyzed and their lower limits of determination are 1 isted in table 2. Spectrographic results were obtained by visual comparison of spectra derived from the sample against spectra obtained from standards made from pure oxides and carbonates. Standard concentrations are geometrically spaced over any given order of magnitude of concentration as follows: $100,50,20,10$, and so forth. Samples whose concentrations are estimated to fall between those values are assigned values of $70,30,15$, and so forth. The precision of the analytical method is approximately plus or minus one reporting interval at the 83 percent confidence level and plus or minus two reporting intervals at the 96 percent confidence level (Motooka and Grimes, 1976). Values determined for the major elements (iron, magnesium, calcium, and titanium) are given in weight percent; all others are given in parts per million (micrograms/gram). Analytical data for samples from the Little Lake Canyon and Owens Peak Wilderness Study Areas are listed in tables 3-6.

\section{ROCK ANALYSIS STORAGE SYSTEM}

Upon completion of all analytical work, the analytical results were entered into a computer-based file called Rock Analysis Storage System (RASS). This data base contains both descriptive geological information and analytical data. Any or all of this information may be retrieved and converted to a binary form (STATPAC) for computerized statistical analysis or publication (VanTrump and Miesch, 1976).

\section{DESCRIPTION OF DATA TABLES}

Tables 3-6 list the analyses for the samples of stream sediment and heavy-mineral concentrate. For the four tables, the data are arranged so that column 1 contains the USGS-assigned sample numbers. These numbers correspond to the numbers shown on the site location maps (figure 2). Columns in which the element headings show the letter " $s$ " below the element symbol are emission spectrographic analyses. A letter " $N$ " in the tables indicates that a given element was looked for but not detected at the lower limit of determination shown for that element in table 2. If an element was observed but was below the lowest reporting value, a "less than" symbol (<) was entered in the tables in front of the lower limit of determination. If an element was observed but was above the highest reporting value, a "greater than" symbol ( $>$ ) was entered in the tables in front of the upper limit of determination. If an element was not looked for in a sample, two dashes (--) are entered in tables 3-6 in place of an analytical value. Because of the formatting used in the computer program that produced tables 3-6, some of the elements listed in these tables 
(Fe, $\mathrm{Mg}, \mathrm{Ca}, \mathrm{Ti}, \mathrm{Ag}$, and $\mathrm{Be}$ ) carry one or more nonsignificant digits to the right of the significant digits. The analysts did not determine these

elements to the accuracy suggested by the extra zeros.

The spectrographic determinations for elements not listed in tables 3-6 were all below the lower limits of determinations shown in table 1 ;

consequently, the columns for these elements have been deleted from tables 3 , 4,5 , and 6 .

\section{REFERENCES CITED}

Grimes, D. J., and Marranzino, A. P., 1968, Direct-current arc and alternating-current spark emission spectrographic field methods for the semiquantitative analysis of geologic materials: U.S. Geological Survey Circular 591, 6 p.

Motooka, J. M., and Grimes, D. J., 1976, Analytical precision of one-sixth order semiquantitative spectrographic analyses: U.S. Geological Survey Circular 738, $25 \mathrm{p}$.

VanTrump, George, Jr., and Miesch, A. T., 1976, The U.S. Geological Survey RASS-STATPAC system for management and statistical reduction of geochemical data: Computers and Geosciences, v. 3, p. 475-488. 
TABLE 1.--List of duplicate samples collected in the Little Lake Canyon and Owens Peak Wilderness Study Areas, southeastern California

\begin{tabular}{lccc}
\hline Ce11 & Duplicate Cell & Site Duplicate & Analytical Duplicate \\
\hline LL007 & LL006 & LL005 & LL005D \\
LL010 & LL012 & LL011 & LL011D \\
LL023 & LL025 & LL024 & LL024D \\
LL027 & LL029 & LL028 & LL028D \\
OP015 & OP017 & OP016 & OP016D \\
OP032 & OP034 & OP033 & OP033D \\
OP040 & OP038 & OP039 & OP039D \\
OP052 & OP054 & OP053 & OP053D \\
OP057 & OP058 & OP059 & OP059D \\
\hline
\end{tabular}


TABLE 2.--Limits of determination for the spectrographic analysis of rocks and stream sediments, based on a $10-m g$ sample

[The spectrographic limits of determination for heavy-mineral-concentrate samples are based on a 5 -mg sample, and are therefore two reporting intervals higher than the limits given for stream sediments]

Elements Lower determination limit Upper determination limit

Percent

\begin{tabular}{lcc}
\hline Iron (Fe) & 0.05 & 20 \\
Magnesium (Mg) & .02 & 10 \\
Calcium (Ca) & .05 & 20 \\
Titanium (Ti) & .002 & 1 \\
\hline
\end{tabular}

Parts per million

Manganese (Mn)

Silver ( $\mathrm{Ag}$ )

Arsenic (As)

Gold $(\mathrm{Au})$

Boron (B)

Barium ( $\mathrm{Ba}$ )

Beryllium (Be)

Bismuth ( $\mathrm{Bi}$ )

Cadmium ( $\mathrm{Cd}$ )

Cobalt ( $\mathrm{Co}$ )

Chromium (Cr)

Copper (Cu)

Lanthanum (La)

Molybdenum (Mo)

Niobium ( $\mathrm{Nb}$ )

Nickel ( $\mathrm{Ni}$ )

Lead (PD)

Antimony ( $\mathrm{Sb}$ )

$\mathrm{Sc}$ andium ( $\mathrm{Sc}$ )

$\operatorname{Tin}(\mathrm{S} n)$

Strontium (Sr)

Vanadium (V)

Tungsten (W)

Yttrium $(Y)$

Zinc $(Z n)$

Zirconium ( $Z r$ )

Thorium ( Th)
10

0.5

200

10

10

20

1

10

20

5

10

5

20

5

20

5

10

100

5

10

100

10

50

10

200

10

100

$$
\begin{array}{r}
5,000 \\
5,000 \\
10,000 \\
500 \\
2,000 \\
5,000 \\
1,000 \\
1,000 \\
500 \\
2,000 \\
5,000 \\
20,000 \\
1,000 \\
2,000 \\
2,000 \\
5,000 \\
20,000 \\
10,000 \\
100 \\
1,000 \\
5,000 \\
10,000 \\
10,000 \\
2,000 \\
10,000 \\
1,000 \\
2,000
\end{array}
$$




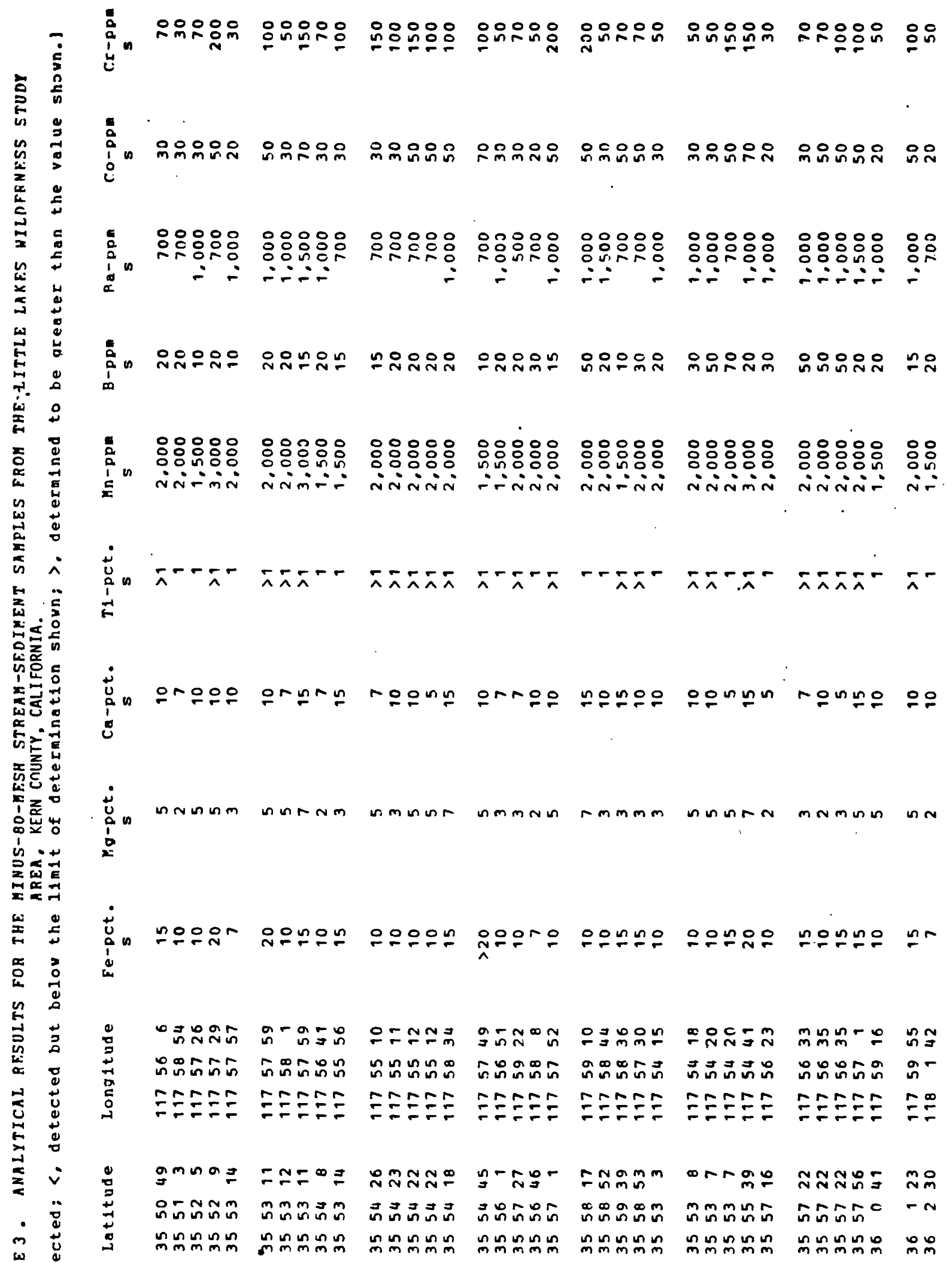




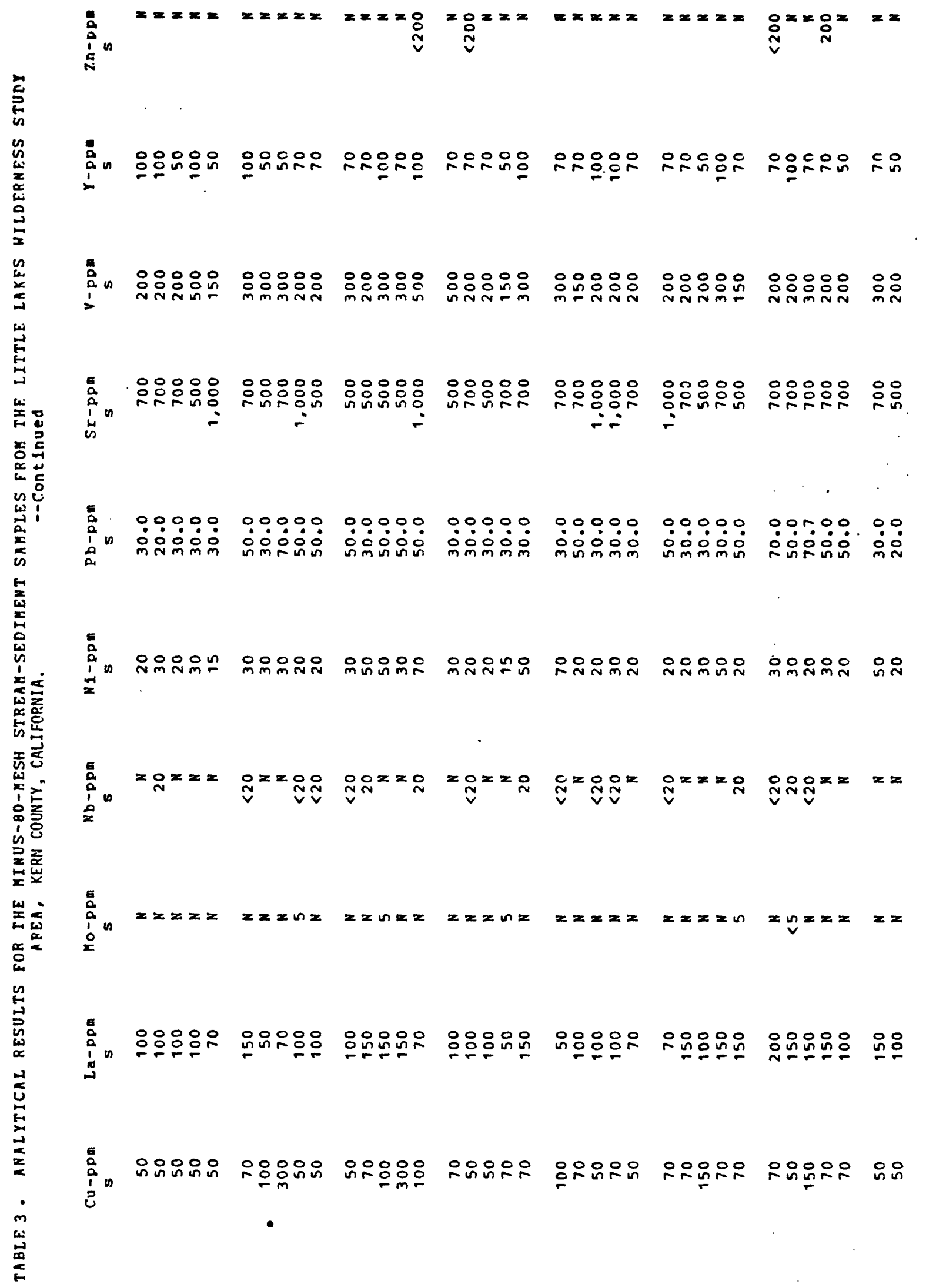

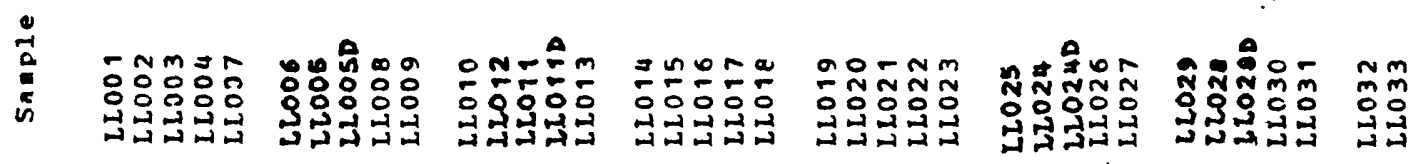




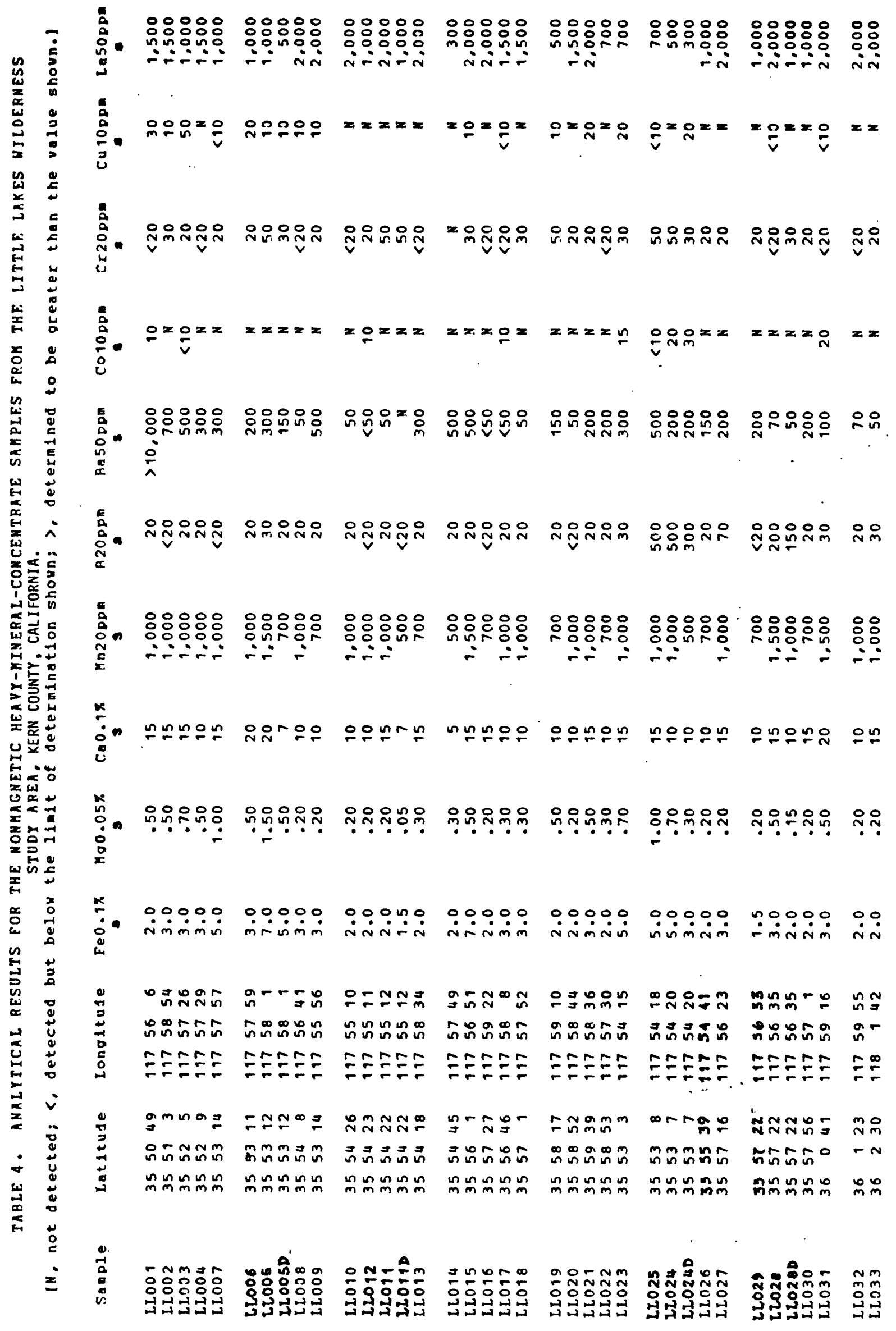




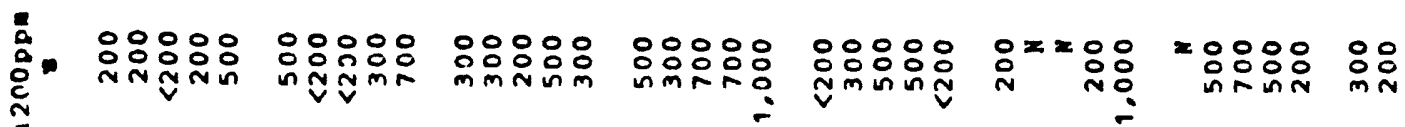

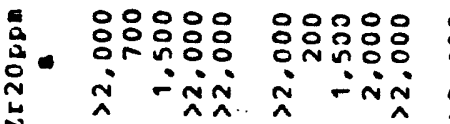

i

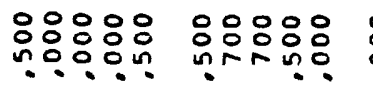

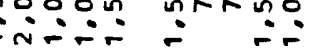

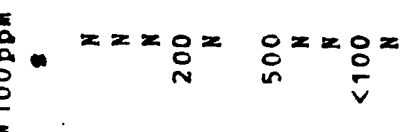

영응영융융

iñin

응응음음

inis

응영융융

ínin

영:80:

iniñi

응융융 :융

iNiñ Nं

용ㅇㅇ 웅요

$\because 0.9 n$

unco:

¿N再

은옹응융용

웅유:

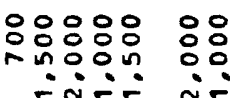

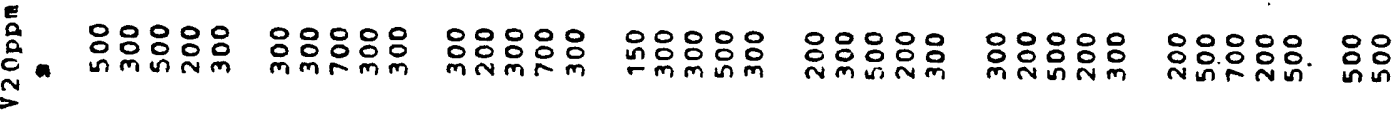

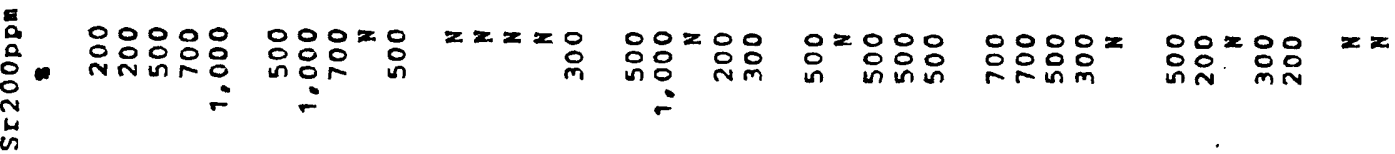

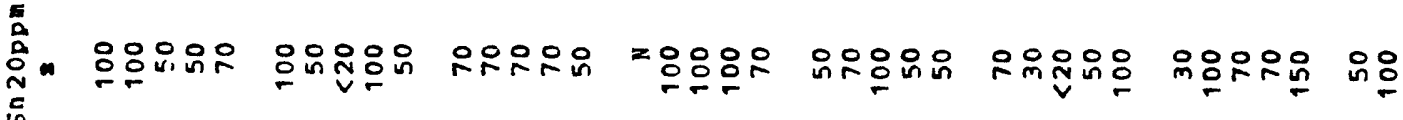

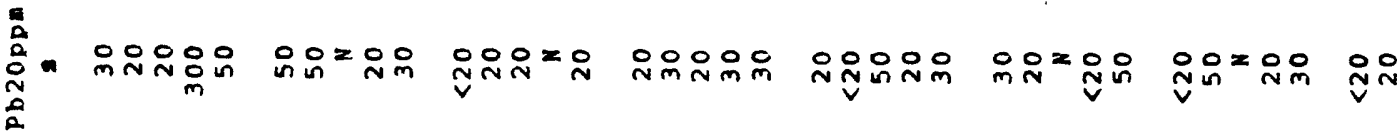

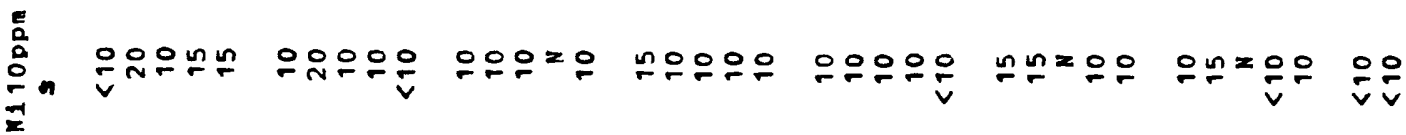

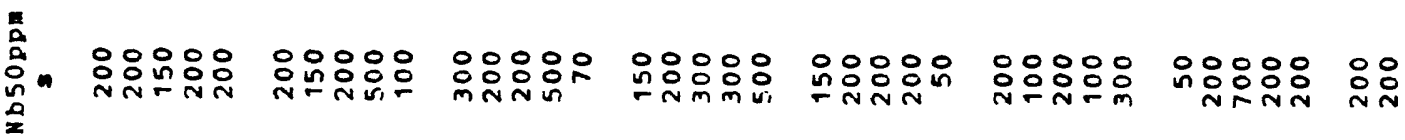

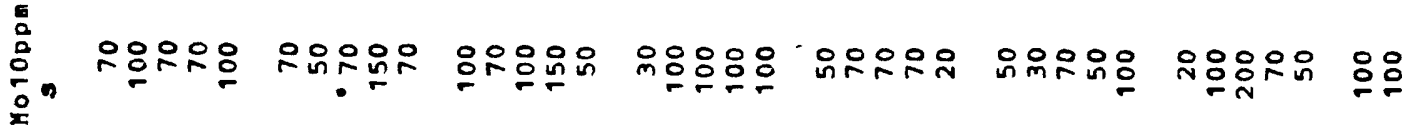

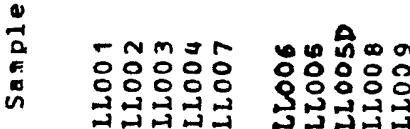

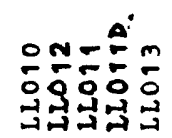

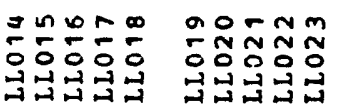

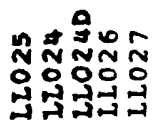

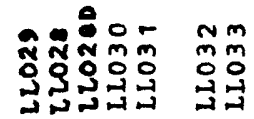




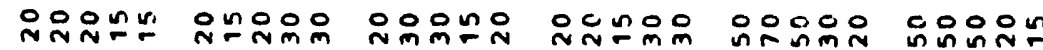

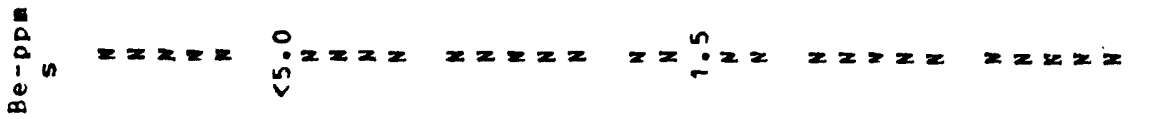

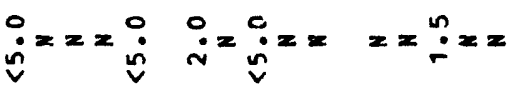

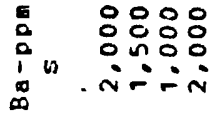
응응ㅇㅇ 응응응 영ㅇㅇ웅 inis:

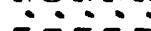

\section{0} in inin

$\therefore \therefore=$

00000

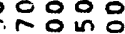

$\therefore \dot{\sim}$

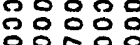
$\because \because-2$

웅ㅇㅇㅇㅇㅇㅇ íni

$00 ㅇ ㅇ ㅇ$ 응응융요 inimin

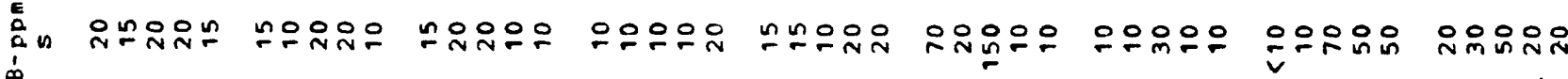
$\dot{\infty}$
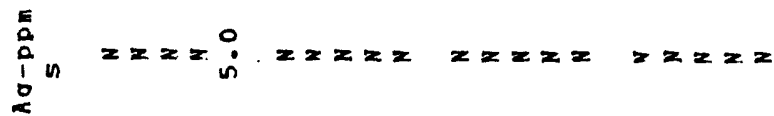

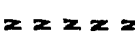

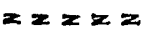

$z x x \geq 2$

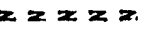

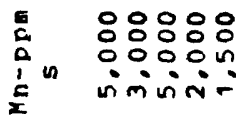

\section{응응웅 \\ $0 \ln 000$}

응응응응응

응응ㅇㅇㅇ응

n?

ininis

응ㅇㅇㅇㅇㅇㅇ

ㅇํㅇㅇㅇํ.

응ㅇㅇㅇㅇㅇㅇㅇㅇ

응ㅇㅇㅇㅇㅇㅇㅇㅇ

응융웅

iminin

$\because \because n$ in

ininis

$: \circ:: 8$

000 ino

NNm-m

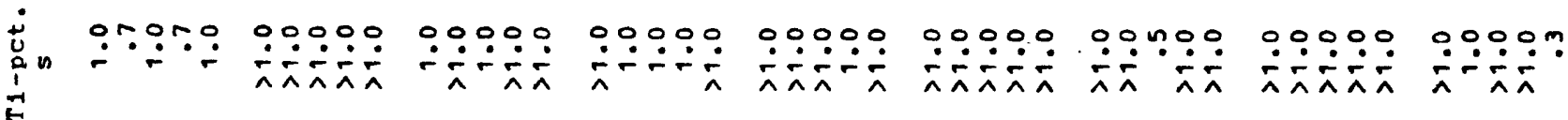

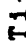

$\wedge \wedge \wedge \wedge \wedge$

A $\lambda \dot{n}$

ヘヘヘヘヘ

$\wedge$ ก

$\underset{\substack{0 \\ i}}{i}$

우웅은

$\min \sin 0$

으는응

요응응

으ㄴㅛㅛ

๓ュュกm

으으유유으

roํํ요

onrro

U⿱

00900

ㅇำ:0ำ

$\because: 0: 0$

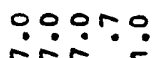

$0: 0$ : $: 0$

00900

00000 :

웅n一n

nm-n

nintion

muinis

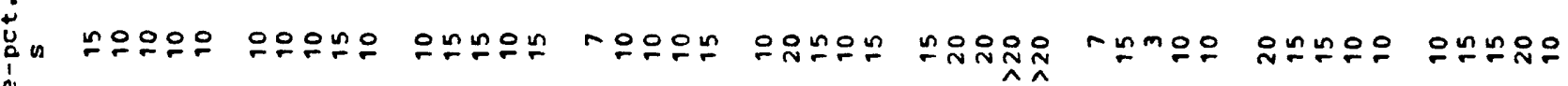
is

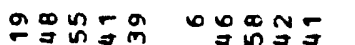

sman

ี

릉

in

응aㄹ

nogror

$=00$ inn

ํํํํำ

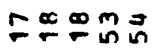

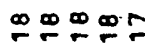

テニテニ

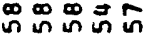

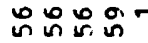

OORN

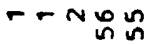

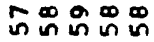

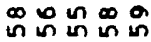

ถิํํㅇำ

$\rightarrow$

キミミます

ニニニニ

$\stackrel{\infty}{=} \underset{\infty}{\infty} \stackrel{\infty}{=}$

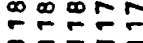

ラニรFร

ニニFニ

キニニニニ

กิกลับับ

ำกำก는

뜸ํㅁㅇㅛ

踏二品

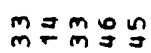

$\exists \underset{m}{*} \stackrel{m}{N}$

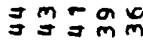

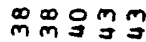

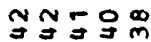

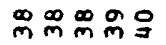

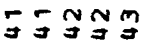

$\vec{\exists} \exists \exists \exists \cong$

莒ำ

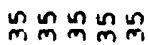

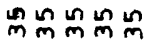

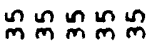

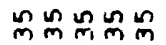

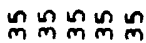

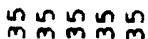

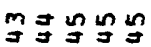

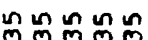

$=\operatorname{mig}_{\exists}^{\infty}=\mathbb{N}$

พำลำำ

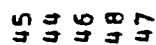

ระฐง

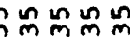

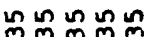

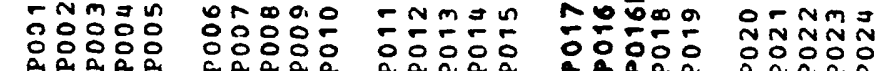

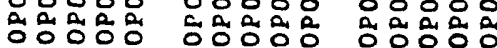




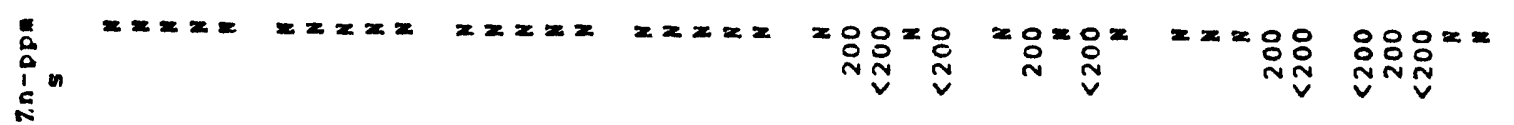

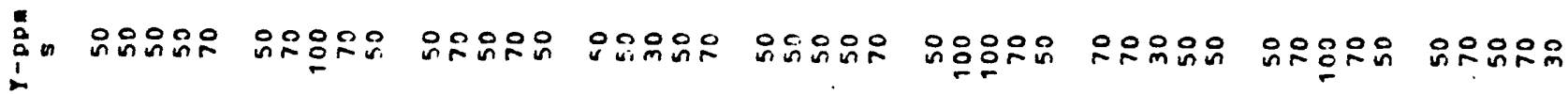

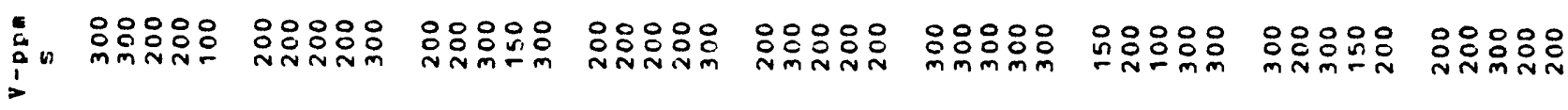

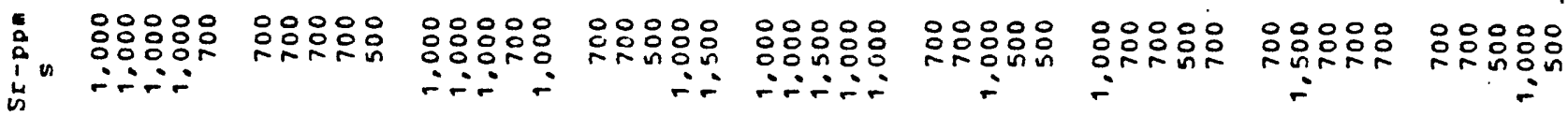

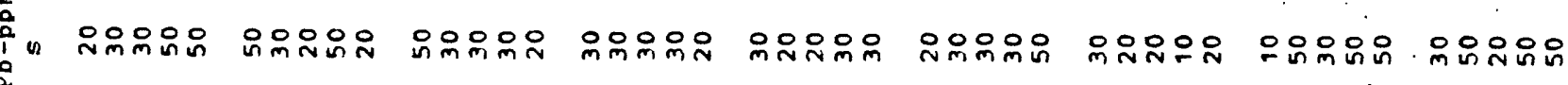

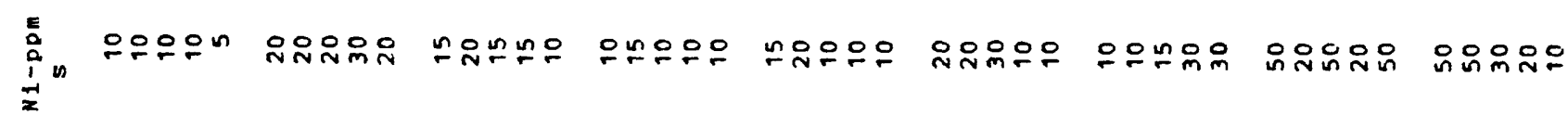

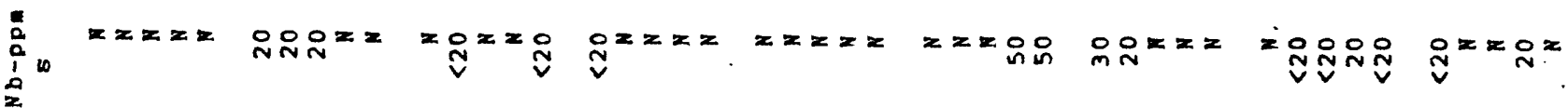

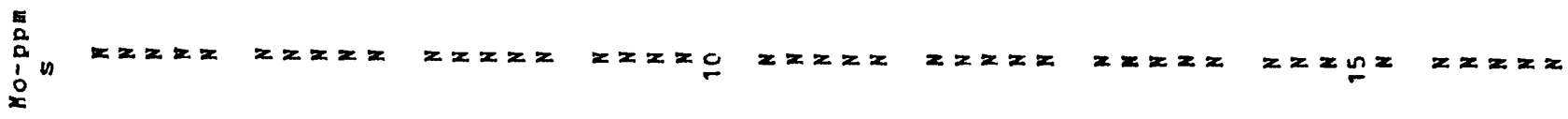

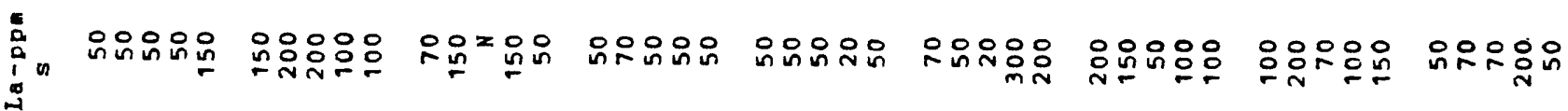

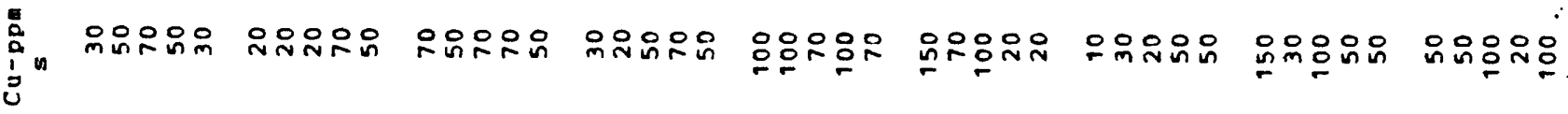

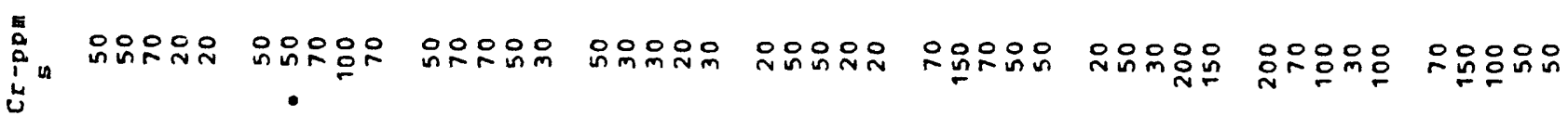
$\underset{m}{2}$

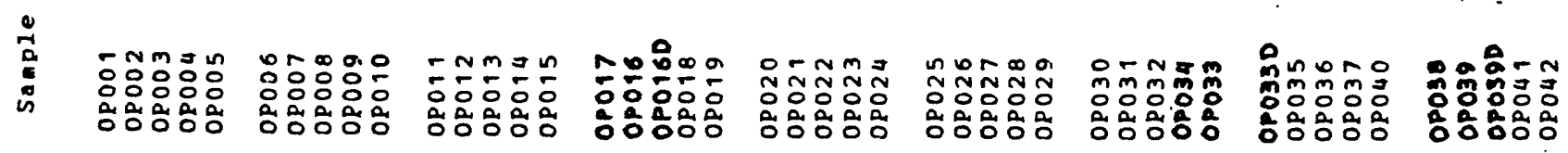




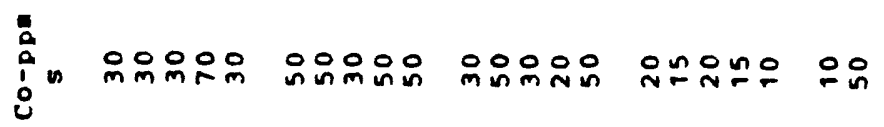

更

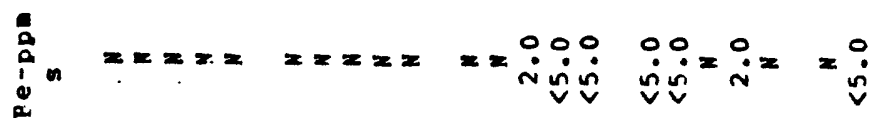

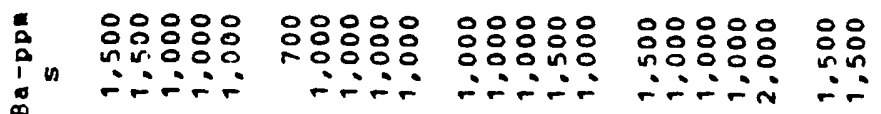

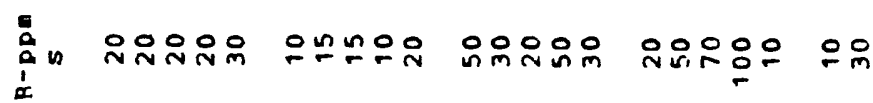

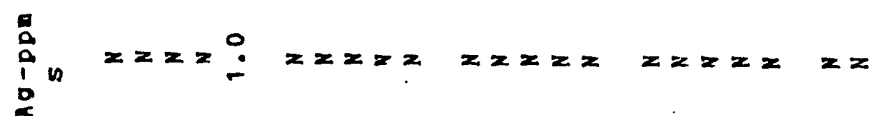

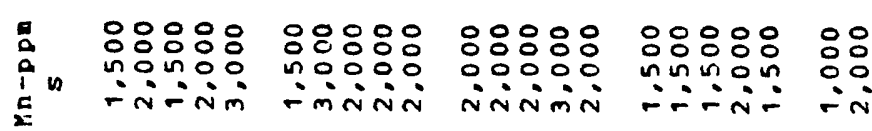
苔

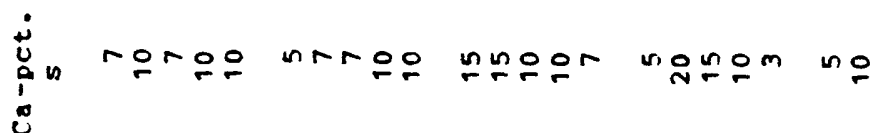

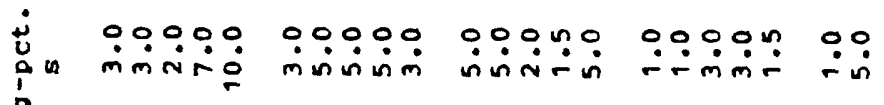
c

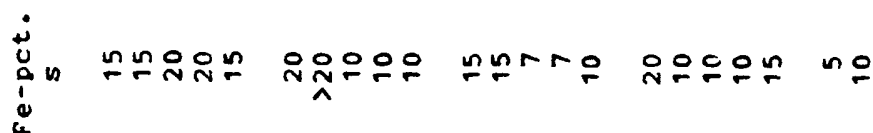

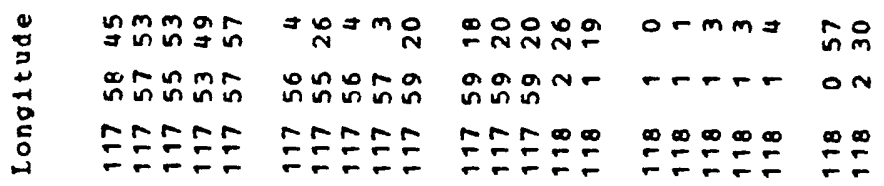

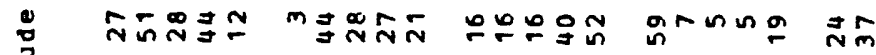

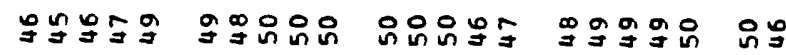

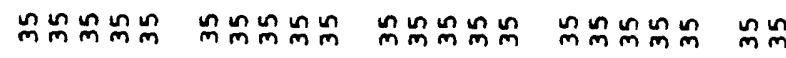

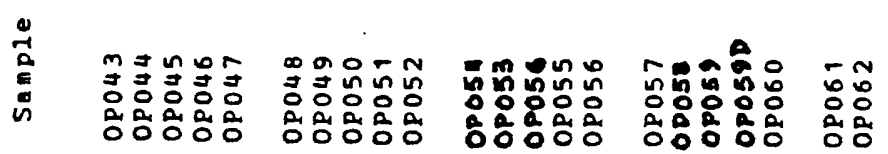




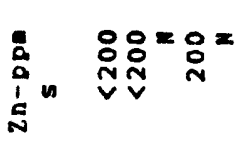

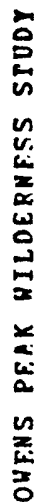

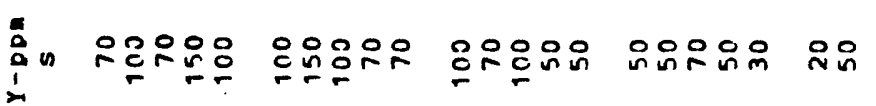

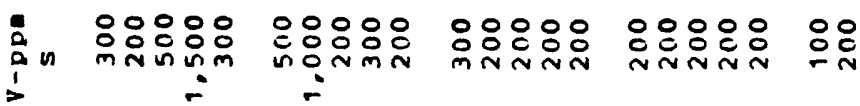

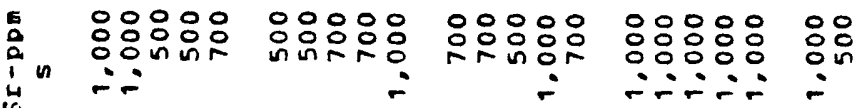



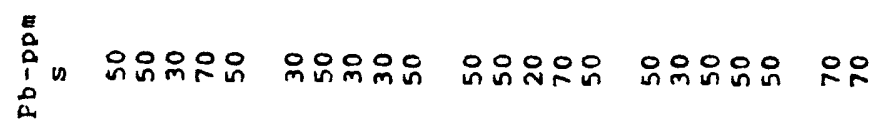

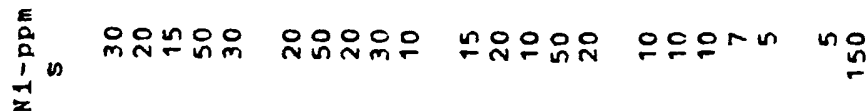

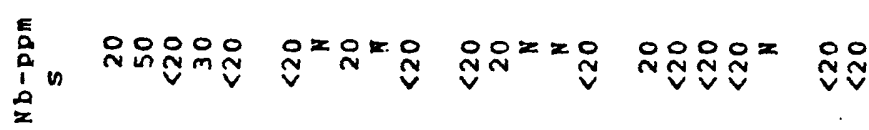

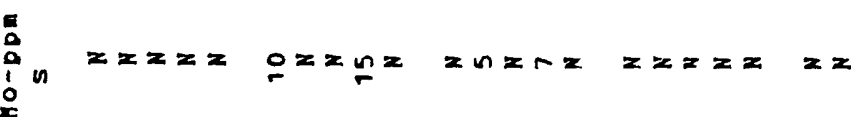

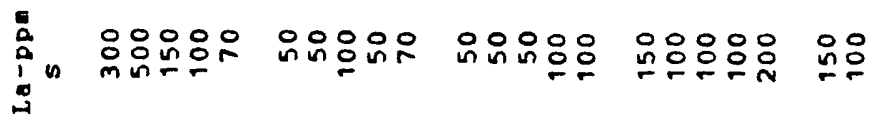

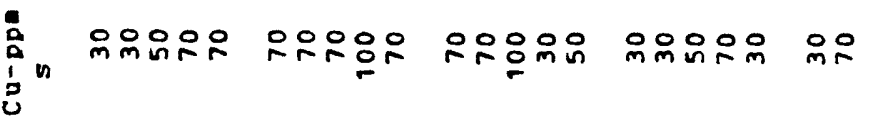

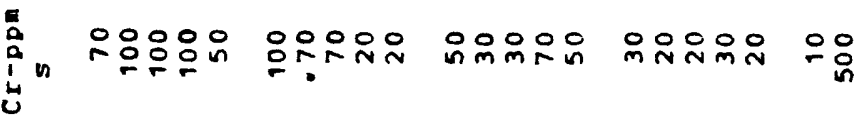

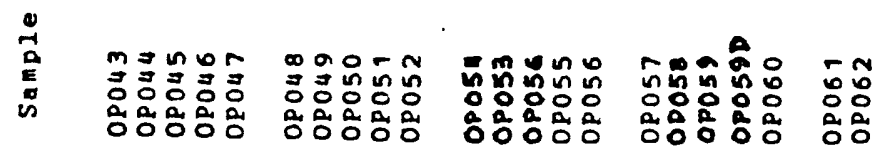




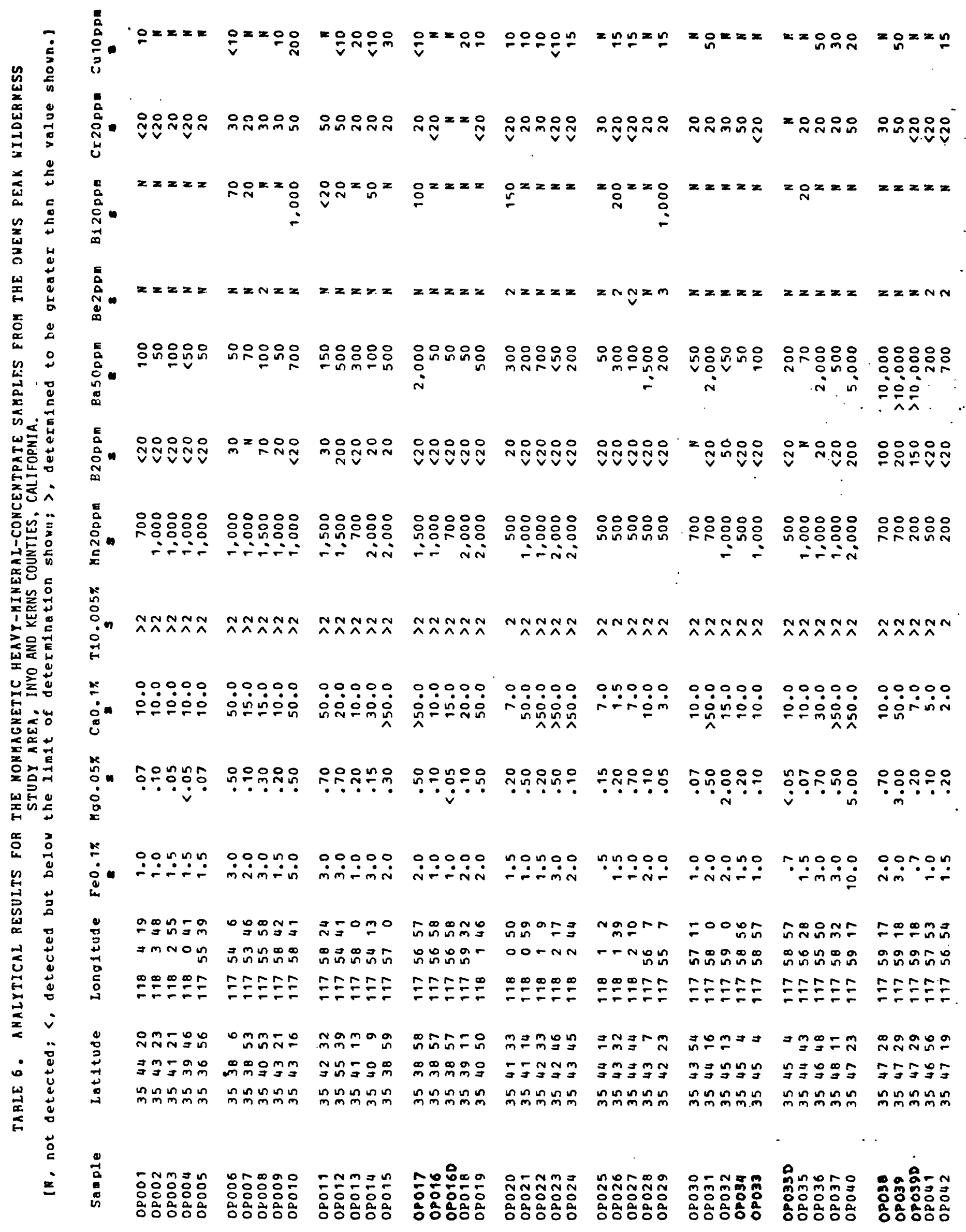




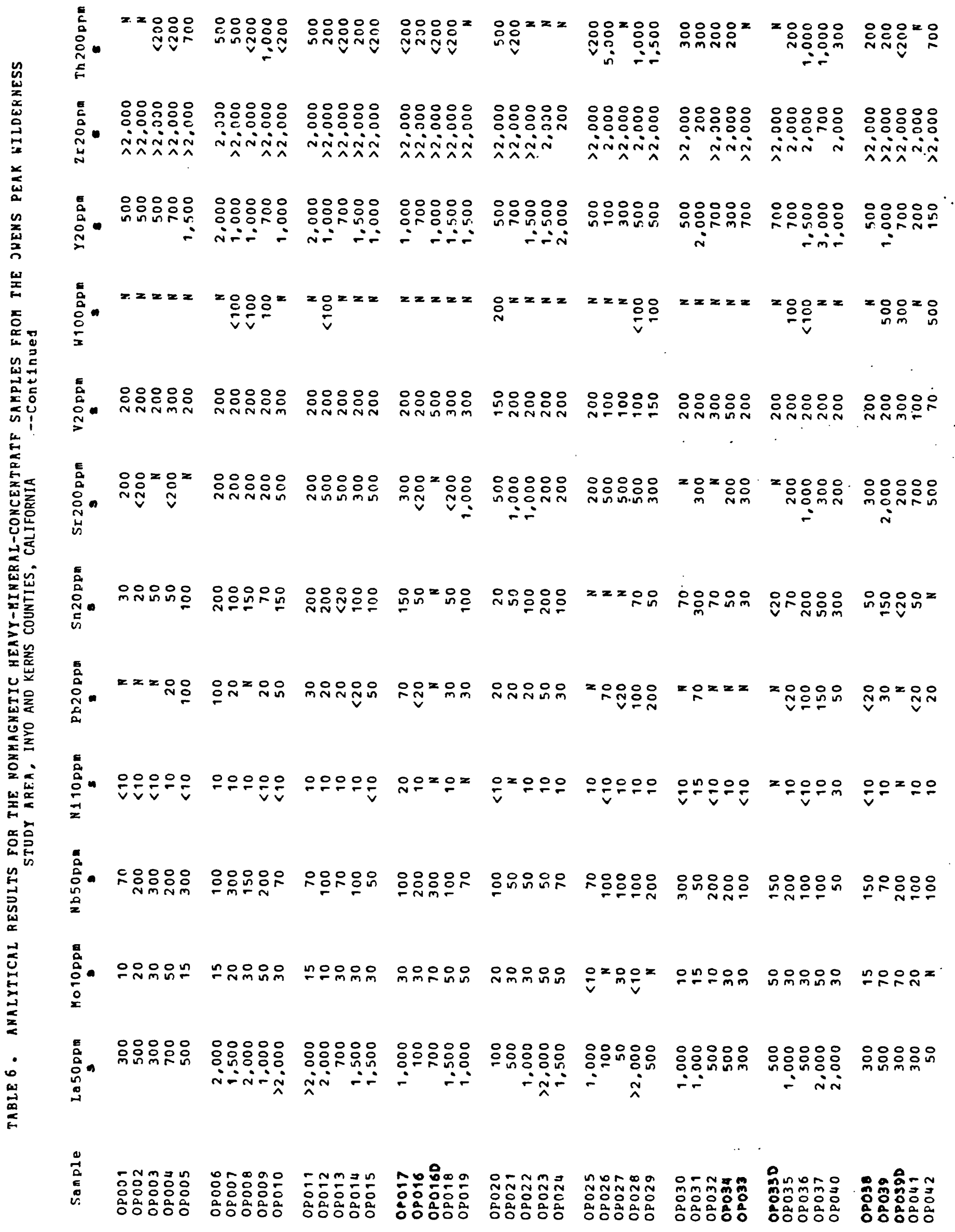




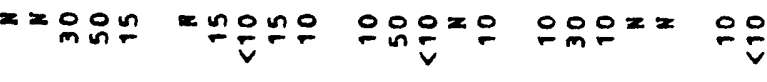

웅

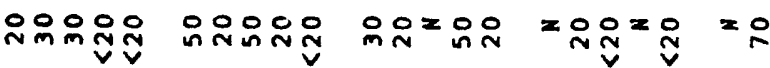

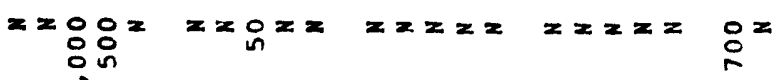

in $\quad \dot{a}$

$\vec{\alpha}$

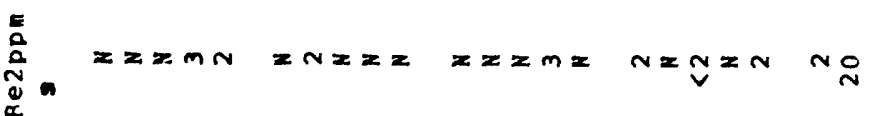

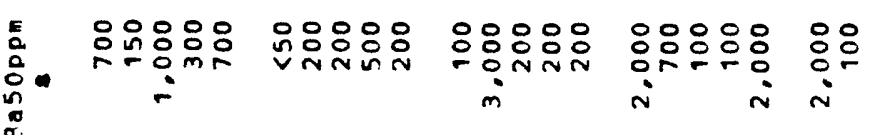

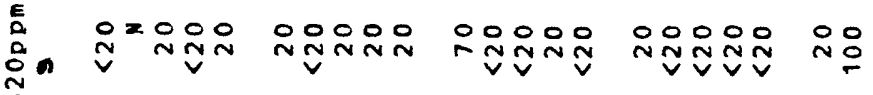

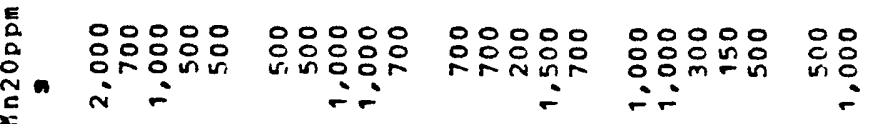

告

NNNNN NNNNN

0000000000000000000000

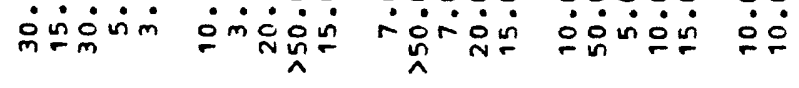

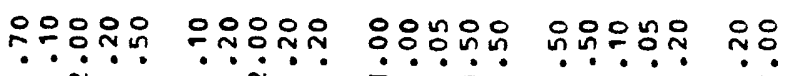

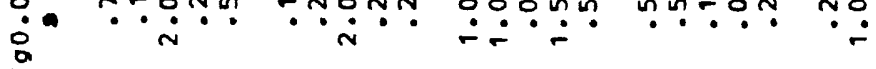

:

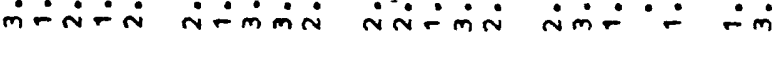

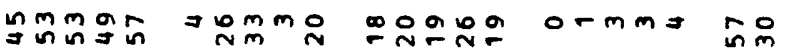

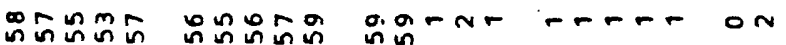

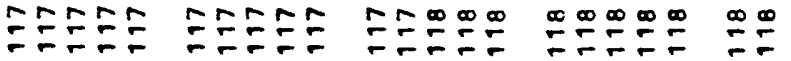

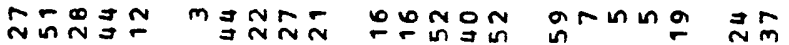

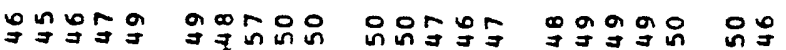
minmmnn

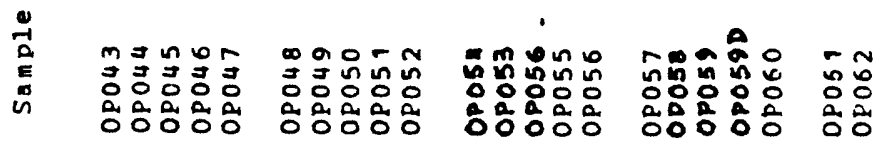




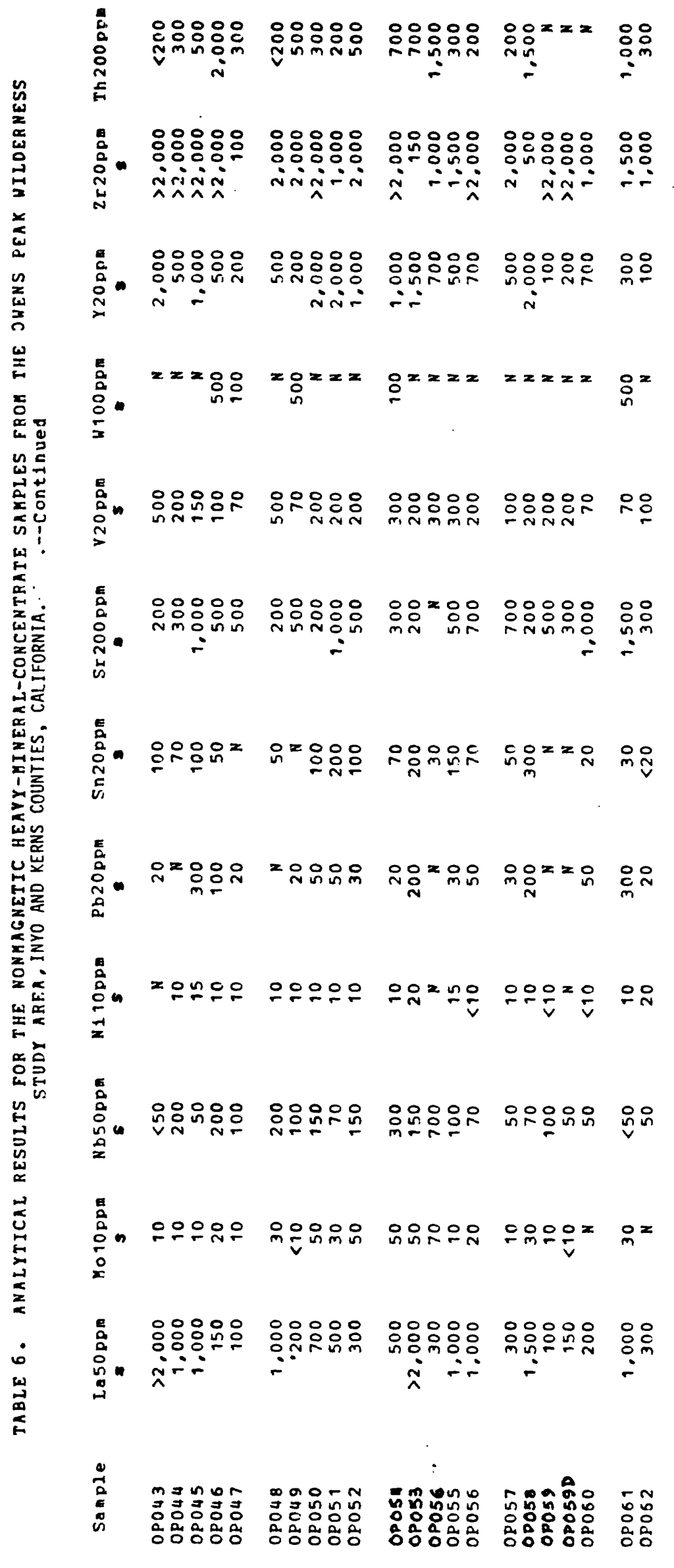

